\title{
Auditing Drug Therapy - Special Problems in Less Developed Countries
}

Prof. Iwan Darmansjah, dr.

\begin{abstract}
Abstrak
Tujuan mengaudit pengobatan ialah untuk menegakkan terapi yang rasional dengan memperhitungkan efisiensi dan biaya yang dikeluarkan. Audit pengobatan sudah lama dilakukan profesi kedokteran dan dapat mencakup ronde di bangsal, membandingkan penggunaan obat dengan pengobatan standard yang berlaku, mensurvey resep di apotik atau rumah sakit, hingga mengumpulkan angka penjualan obat secara nasional atau studi pemakaian obat lainnya. Tidak perlu dirisaukan adanya pengungkapan rahasia jabatan karena identitas dokter atau penderita tidak dibeberkan. Audit pengobatan masih perlu ditingkatkan di negara berkembang. Berbagai hambatan dijumpai yang berdasarkan kurangnya keterbukaan dalam mengelola penderita.
\end{abstract}

\section{Abstract}

The purpose of auditing drug therapy is clearly to establish rational use of drugs in a cost-effective way. Therapeutic drug audits has been known and practiced since the beginning of the medical profession and includes : bedside therapeutic rounds, therapeutic conferences, comparing treatment schedules with standards, prescription surveys in pharmacies and hospitals, drug utilization studies, to national sales figures. Violation of medical ethics need not be hampering its performance since the identity of the patient and the attending doctor are kept confidential. Therapeutic audits in developing countries are not popular presumably because of the difficulty to accept criticism and to find valid reasons for using a drug; hereby impeding the rationality of prescribing.

Keywords : Audit, Drug audit, Therapeutic audit, Therapeutic drug audit

\section{INTRODUCTION}

Audit means originally "an official examination of the accounts of a business, society, etc., usually done once a year". ${ }^{1}$ When business and other enterprises should be audited, an activity or profession that uses drugs which involves human lives must logically be audited too. Therapeutic drug audits (drug audits) therefore means checking whether drugs were used properly and rationally. It must therefore accept some standards for comparison. While therapeutic practices may differ from place to place, this means that in accepting standards of treatment one may not use a rigid gold standard and must differentiate between small and bigger deviations from the standard. Only the great deviations should be regarded as irrational. In order to make valid judgements it is important that the use of a drug be linked to its indication.
The ultimate purpose of auditing drug therapy is clearly to establish rational use of drugs in a cost effective way. ${ }^{2,3,4}$ Physicians, patients, and the public are reluctant to accept cost containment as a rational approach to limit physicians activities in prescribing. Therefore, when expenditure of drugs becomes critical, actions to minimize spending should be based on rationality and scientific criteria rather than the mere control of expenses. When applying rationality in drug treatment, cost of treatment will automatically be reduced at the same time. An analogy can be drawn from the Essential Drugs Concept, ${ }^{5}$ which for falsely political reasons, were only meant for poor countries. A discrimination against poor countries of this sort is perhaps difficult to accept. Moreover, not all inhabitants in a poor country are poor. Now, the afluent countries are even in great need of limiting its previously wasteful drug expenditure, and again cost has been used as the scapegoat instead of irrationality. 
The dangers of treatment were already included in Hippocrates' wise statement: primum non nocere. Judgement whether individual treatment was harmful had begun in the clinics since therapeutic rounds had been customary in hospital wards, but formal drug audits and drug epidemiological studies have been initiated only more than a decade ago, presumably accelerated by the WHO Drug Policy and Essential Drugs Programme. The increasing availability of pharmaceuticals in the world has logically resulted in overconsumption of drugs and these would be easily identified by properly conducted drug audits.

With such apparent benefits of therapeutic drug audits, developing countries should need them most. The appreciation of rationality and cost, however, may differ at different places. Table 1 attempts to list the need for drug audits in relation to rationality and cost. As medical care moves from reimbursement of expenses to private payment, motives to do drug audits become less conspicuous. Medical care in different countries vary very much, but the trend is towards more privatization as governments can no longer cope with the rising health costs. This could result in lesser motives to do drug audits unless patients demand their rights; a very unlikely thing to occur in less developed countries (LDCs).

Table 1. Relative need for Drug Audits

\begin{tabular}{lcc}
\hline Medical Care & Rationality & Cost \\
\hline Government budget & +++ & +++ \\
Partly subsidized & ++ & ++ \\
Insurance system & +++ & +++ \\
Privatized & + & + \\
\hline
\end{tabular}

With the increasing privatization of health as part of the impact of the global trend towards a democratic economy, I would fear that the LDCs, especially those that are emanating out from poverty, would lose the image and examples of a good (social) health system such as that in the U.K. and Sweden. LDCs will be transformed too fast into health privatization, while still most of its population will not be capable of paying for their own health care.

Ideally, rationality should be the prime reason to conduct drug audits, but money would be usually a stronger motive to initiate it. The results of drug audits must be properly interpreted in order to make corrections accordingly.

\section{MATERIALS AND METHODS}

In order to get an overview of drug audits in developing countries a questionnaire was sent to some 20 pharmacologists and pharmacists in selected countries. Twelve responded to a 2 pages fill-in form and the results are presented below. Responses came from China, India, Indonesia, Malaysia, Nepal, Nigeria, Philippines, Singapore, and Thailand.

\section{RESULTS AND DISCUSSION}

Some form of drug audits were done in all these countries but one, which is currently planning to conduct such a study. In general, very little enthusiasm was shown towards drug audits and the number of published studies are very limited.

The type of audit is very variable, from bedside therapeutic rounds, matching the use of drugs with standard treatments, comparing treatment schedules and doses, prescription studies in pharmacies and hospitals, to national sales figures. Often no reference is made to the indication for which the drug(s) is/are given. Audits using global national drug consumption figures such as practised in Scandinavian countries ${ }^{6}$ can not be done properly in developing countries due to lack of dependable computerized data. IMS, however, produces national drug sales figures (Indonesian Pharmaceutical Audit) derived from sampled pharmacies in each country, but these are confidential industrial property. The main problem with these data of course is that the use of the drug cannot be related to its indication. Diseases most studied were diarrhea, upper respiratory tract infections and surgical prophylaxis with antibiotics.

Some of the results obtained are indeed hair-raising. A general overuse of antibiotics of up to $94 \%$ were found for acute respiratory infections (mostly viral), prolonged prophylaxis with antibiotics on clean operations, unneeded injections, overconsumption of vitamins and corticosteroids, etc. Despite the availability of clear guidelines, an unpublished study in three Health Centres in Jakarta ${ }^{7}$ recently reported the use of antibiotics in common diarrhea in $83-88 \%$ of cases. Oral rehydration fluid however was given properly in $75-89 \%$. Some $60 \%$ of all drug costs on children below 5 years has been spent on anti-diarrheals and $33 \%$ was spent on respiratory tract drugs. This phenomenon was in agreement with the incidences of diseases for children below 5 years. It should be noted that underuse of drugs has also been signaled with drugs like opiates, penicillin-V, and penicillin-G. 
There was substantial use of drugs that are not available in developed countries; these were mostly useless and ineffective drugs, sometimes toxic, which were allowed and left on the market by incompetent regulatory authorities. Not least responsible are the drug companies, many of them multi-nationals, that apply double standards in their marketing practices. They form a large waste of funds for LDCs because these drugs are high-priced, consumed for long periods and are ironically much presribed. Examples of such drugs are: carbazochrome to stop bleeding, proteolytic enzymes after every operation and any inflammation, ATP orally to boost energy, Isoprinosine to be given to any virus infection and immune deficiency, low dose potassium salts of which one should take at least 10-15 tablets per dose when really needed, "hepatic protectors" claimed to improve acute and chronic hepatitis brain activators to let one remember better, useles fixed combinations which are sometimes dangerous, etc. In a revaluation schedule by the Indonesian Food and Drug Authority, 285 drug formulations belonging to 11 drug classes were banned in October 1991. This should be followed by other classes of drugs.

Inappropriateness of medication stemmed mainly from wrong indication and wrong drug selection; this then is followed by wrong treatment schedule and wrong dosing. There was a conspicious difference of rationality applied in prescribing between physicians working in the government and the private sector; these were openly admitted by prescribers in interviews.

Doing drug audit in developing countries is not always easy. Each of the respondents mentioned difficulties of variable nature. Some of the real problems encountered were a.o. unwillingness of respondents (including patients) to fill in questionnaires, funds to do the study is often lacking (priorities falsely perceived), acceptable treatment standards are often absent, and badly maintained medical records in hospitals. There certainly are many more problems and it seems that the challenges towards LDCs lie deeper than the skin. Three main problems can be identified which are: sociocultural, educational and infrastructural. These factors no doubt contribute to the problem of irrational use of drugs and the acceptance of conducting drug audits. Mystique and folkloric belief often are more dominant than logic and rationality among patients and doctors as well. I think the socio- cultural problems are the most important and difficult to overcome because they include things like: beliefs, opinions, habit, tradition, attitude, behaviour, openness, frankness, norms, values, perception, emotion, enthusiasm, wisdom and perhaps philosophy.

Most studies that are done are not published or may appear in local journals. Sometimes the results of the study are communicated to the prescribers, but most often very little change in prescribing behaviour can be observed. When changes do take place it may not stay for very long. An important aspect to change drug-use behaviour is to distribute hard, convincing, and scientific evidence. But if these do not change prescribing patterns, very little can be done indeed, except enforcement by some kind of regulation. This has been successfully applied to the use of essential drugs in government hospitals and primary health centres in many LDCs.

Let me not end by giving you the impression that irrational prescribing is a vice of LDCs only. The problem is also present in developed countries, only the magnitude may be different. Very few comparative studies have been done indeed. Another important fact to be observed is that corrective measures are more readily taken in a developed country.

\section{REFERENCES}

1. Procter P, editor. Longman Dictionary of Contemporary English. Essex: Longman Group Ltd, 1978.

2. Russell IT, Addington-Hall JM, Avery PJ, Bamford CH, Barton AG, Donaldson $\mathrm{C}$ et al. Medical audit in general practice. I: Effects on doctors' clinical behaviour for common childhood conditions. Br Med J 1992;304/6840; 1480 4.

3. Hurley SF, McNeil JJ, Jolley DJ, Harvey R. Linking prescription and patient-indentifying data: A pilot study. Med J Aust 1992;156/6:383-6.

4. Jones AC, Berman P, Doherty M. Non-steroidal anti-inflammatory drug usage and requirement in elderly acute hospital admissions. Br J Rheumatol 1992;31/1:45-8.

5. WHO Technical Report Series, No.615, 1977. The selection of essential drugs.

6. Nordenstam I, Wennberg M, Kristoferson K. Svensk Lakemedels-Statistik. Stockholm : Apoteksbolaget, 1991.

7. Gani L, Arif H, Widjaya SK, Tampubolon LH. Management for acute diarehea in young children by public and private physicians in Jakarta: A Report from Atmajaya University, 1991. 